\title{
Randomised comparison of oral and vaginal misoprostol when combined with mifepristone for termination of second trimester pregnancy
}

\author{
Madhuri N. ${ }^{1}{ }^{*}$, Veena G. R. $^{2}$, Manjunath G. H. $^{2}$
}

${ }^{1}$ Department of Obstetrics and Gynaecology, J.S.S Medical College, Mysore, Karnataka, India
${ }^{2}$ Department of Obstetrics and Gynaecology, J.J.M medical college, Davangere, Karnataka, India

Received: 15 January 2016

Accepted: 02 February 2016

\section{*Correspondence:}

Dr. Madhuri N.,

E-mail: drmadhuri.n@gmail.com

Copyright: (C) the author(s), publisher and licensee Medip Academy. This is an open-access article distributed under the terms of the Creative Commons Attribution Non-Commercial License, which permits unrestricted non-commercial use, distribution, and reproduction in any medium, provided the original work is properly cited.

\section{ABSTRACT}

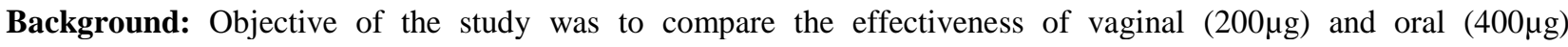
misoprostol when combined with mifepristone $(200 \mathrm{mg})$ in termination of second trimester pregnancy.

Methods: 60 women who were pregnant between 13 and 20 weeks were included in the study. They were divided into two groups by random sampling method and they all received $200 \mathrm{mg}$ of mifepristone orally on day 1.36 hours later they received $200 \mu \mathrm{g}$ of misoprostol vaginally or $400 \mu \mathrm{g}$ of misoprostol orally every 3 hours as determined by the random sampling method. Main outcome measures were induction abortion interval, complete abortion rate and side effects.

Results: There was a statistical difference in the amount of misoprostol required in the oral and the vaginal group, the total dose being higher in the oral group. The mean induction-abortion interval in the vaginal group was $6.2 \mathrm{hrs}$ and oral group was $11.6 \mathrm{hrs}$ and this difference was statistically significant. There was no statistical difference in the complete abortion rate of the two groups. There was no difference in the side effects caused by both routes of misoprostol administration.

Conclusion: $200 \mu \mathrm{g}$ misoprostol inserted vaginally is better than $400 \mu \mathrm{g}$ of oral misoprostol, 36 hours after administration of tab. Mifepristone $200 \mathrm{mg}$ for termination of second trimester pregnancy.

Keywords: Mifepristone, Second trimester medical abortion, Misoprostol

\section{INTRODUCTION}

Advances in fetal diagnosis have resulted in increased number of second trimester pregnancy terminations. Invasive means of second trimester medical abortion have long been available. In the past few years, however, the ability to safely and effectively accomplish non invasive second trimester abortions has evolved considerably.

A combination of mifepristone, a progesterone antagonist, and misoprostol, a synthetic prostaglandin E1 analogue, is effective for medical abortion in second trimester. The latter has the advantages of being cost effective, stable at room temperature and is a strong uterotonic. Mifepristone, (RU 486, a substitute 19norethisterone derivative) is a progesterone receptor blocker, causes intrauterine fetal demise and sensitises the uterus to the activity of prostaglandins. ${ }^{1}$ The two drugs together have proven efficacy in first trimester abortion. $^{2}$

The optimal regimen for second trimester is still under investigation, but is required to have a high complete abortion rate, short induction-abortion interval, low 
incidence of side effects, decreased surgical intervention and high acceptability.

Misoprostol can be administered through oral or vaginal route but its adverse effects like vomiting, diarrhea, fever, abdominal pain are still of concern.

Efforts to optimize the route and dose of misoprostol, to maximize the effectiveness and minimize side effects are important.

This study is therefore designed to test whether oral administration of misoprostol (400 $\mu \mathrm{g}$ every 3 hours) is as optimal as vaginal administration (200 $\mu$ g every 3 hours) of misoprostol when pretreated with $200 \mathrm{mg}$ of mifepristone 36 hours prior, for termination of second trimester pregnancy.

\section{METHODS}

The study was conducted on 60 healthy women (aged between 16 and 35 years) with singleton intrauterine pregnancy (confirmed by ultrasound) between 13 and 20 weeks of gestation admitted for legal termination of pregnancy to the teaching hospitals attached to J.J.M. Medical College during the study period of 2 years from November 2009 - 2011.

Grand multipara, multiple pregnancies, patients with Bronchial asthma, Cardiac disease, Renal disease, Liver disease, previous caesarean section, allergy to prostaglandins, Ruptured membranes and Hemorrhagic disorders and patients on treatment with anticoagulants were excluded.

Women who fulfilled the above criteria were counselled and given details of the study. Informed written consent was obtained from each patient. Selected patients were registered, detailed history noted, routine investigations were sent and gestational age was confirmed by dates and ultrasound.

Each of the patients were allocated to one of the groups by coloured coins method (self selection - random sampling method).

- Group I: vaginal misoprostol $(200 \mu \mathrm{g})$ every 3 hours.

- Group II : oral misoprostol $(400 \mu \mathrm{g})$ every 3 hours

Each patient was given 200mg mifepristone and 36 hours later misoprostol was given orally or vaginally according to the random allocation. This was an open study where both the investigators and the participants knew the dosage and route of administration. Pulse rate, blood pressure, uterine contractions and pelvic examinations were noted every 3 hours.

The side effects nausea, vomiting, diarrhea, headache, fever, severe bleeding were noted. Oral tablets of paracetamol or IM tramadol were provided $4^{\text {th }}$ hourly as required. The induction - abortion interval is defined as time taken from initial insertion of misoprostol until expulsion of fetus. If placenta was complete, no further interventions were undertaken. If placenta was incomplete or failed to get expelled after 1 hour, surgical evacuation was done.

Complete abortion is defined as the expulsion of fetus and placenta without operative interventions. If abortion did not occur with this regimen (within 3 hours of the $5^{\text {th }}$ dose of misoprostol) a second course of misoprostol was given. If abortion still failed to occur then pregnancy was terminated with extra amniotic ethacridine lactate instillation.

Patient was observed in the wards for a minimum 6 hours after complete expulsion. Rh antibody was given to all $\mathrm{Rh}$ negative cases. All women were given follow up appointment within 2 weeks of termination.

Chi-square test for categoric data and student ' $t$ ' test for continuous data was used to compare the differences in the two groups. Differences were regarded as statistically significant if $\mathrm{P}<0.05$.

\section{RESULTS}

Table 1: Patient data in two groups.

\begin{tabular}{|lllll|}
\hline $\begin{array}{l}\text { Informa } \\
\text { tion }\end{array}$ & & $\begin{array}{l}\text { Group I } \\
\text { (vaginal) }\end{array}$ & $\begin{array}{l}\text { Group } \\
\text { II } \\
\text { (oral) }\end{array}$ & I Vs II \\
\hline $\begin{array}{l}\text { No.of } \\
\text { cases }\end{array}$ & & 30 & 30 & - \\
\hline $\begin{array}{l}\text { Age } \\
\text { (Yrs) }\end{array}$ & $\begin{array}{l}\text { Mean } \pm \\
\text { SD }\end{array}$ & $23.0 \pm 3.5$ & $\begin{array}{l}23.1 \pm \\
2.3\end{array}$ & $\begin{array}{l}\text { P=0.89, } \\
\text { NS }\end{array}$ \\
\hline & Range & $\begin{array}{l}19-35 \\
\text { years }\end{array}$ & $\begin{array}{l}19-27 \\
\text { years }\end{array}$ & \\
\hline $\begin{array}{l}\text { GA } \\
\text { (weeks) }\end{array}$ & Mean \pm & $16.5 \pm 3.0$ & $\begin{array}{l}15.9 \pm \\
2.9\end{array}$ & $\mathrm{P}=0.43$, \\
& Range & $\begin{array}{l}12-20 \\
\text { weeks }\end{array}$ & $\begin{array}{l}12-20 \\
\text { weeks }\end{array}$ & \\
\hline Parity & Primi & $\begin{array}{l}13 \\
(43.3 \%)\end{array}$ & $\begin{array}{l}8 \\
(26.7 \%)\end{array}$ & $\mathrm{PS}=0.18$, \\
\hline & Multi & $\begin{array}{l}17 \\
(56.7 \%)\end{array}$ & & \\
\hline
\end{tabular}

In our study the youngest patient was 19 years old and the oldest was 35 years old. Mean age was 23 in both groups. The mean gestational age was 16.5 weeks in group I and 15.9 weeks in group II. There was no statistical differencein the mean age or gestational age distribution in between the two groups. There was no statistical difference of parity among the two groups. 


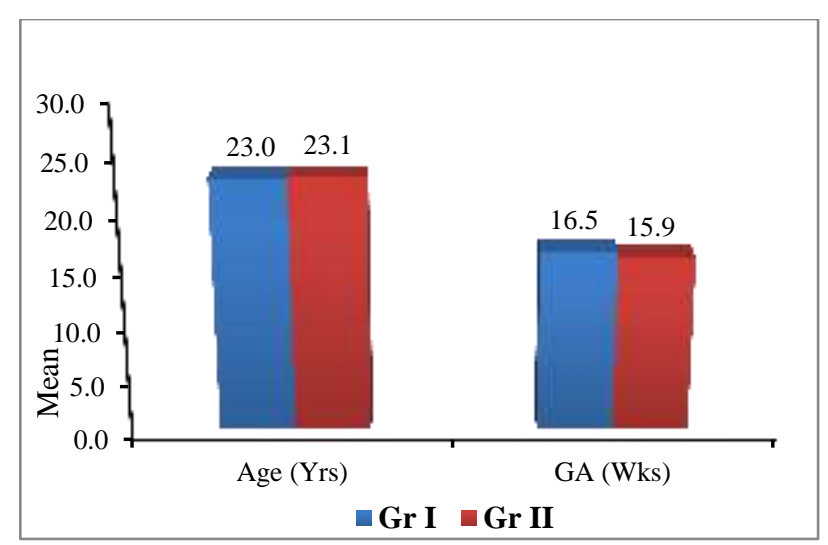

Figure 1: Maternal age (yrs) and gestational age (wks) in two groups.

Table 2: Number of doses in two groups.

\begin{tabular}{|lll|}
\hline No. of doses & Group I $n(\%)$ & Group II $n(\%)$ \\
\hline 1 & $14(46.7)$ & $2(6.7)$ \\
\hline $2-3$ & $15(50.0)$ & $18(60.0)$ \\
\hline $4-5$ & $1(3.3)$ & $10(33.3)$ \\
\hline Total & 30 & 30 \\
\hline
\end{tabular}

Table 3: Mean no. of doses in two groups.

\begin{tabular}{|lll|l|}
\hline Dosage & Group-I & Group-II & I V/S II \\
\hline $\begin{array}{l}\text { Mean no. of } \\
\text { doses } \pm \text { SD }\end{array}$ & $1.8 \pm 0.9$ & $3.0 \pm 1.3$ & $\mathrm{P}<0.05$ \\
\hline Range & $1-4$ & $1-5$ & \\
\hline
\end{tabular}

In group I, $46.7 \%$ aborted with 1 dose of $200 \mu \mathrm{g}$ misoprostol used intravaginally, 50\% aborted with 2-3 doses and $3.3 \%$ with $4-5$ doses. The mean dosage was $1.8 \pm 0.9$. In group II $6.7 \%$ aborted with 1 dose of $400 \mu \mathrm{g}$ misoprostol orally, $60 \%$ aborted with 2-3 doses and $33.3 \%$ needed $4-5$ doses. The mean dosage was $3.0 \pm 1.3$.The difference in distribution of doses in between the two groups was statistically significant.

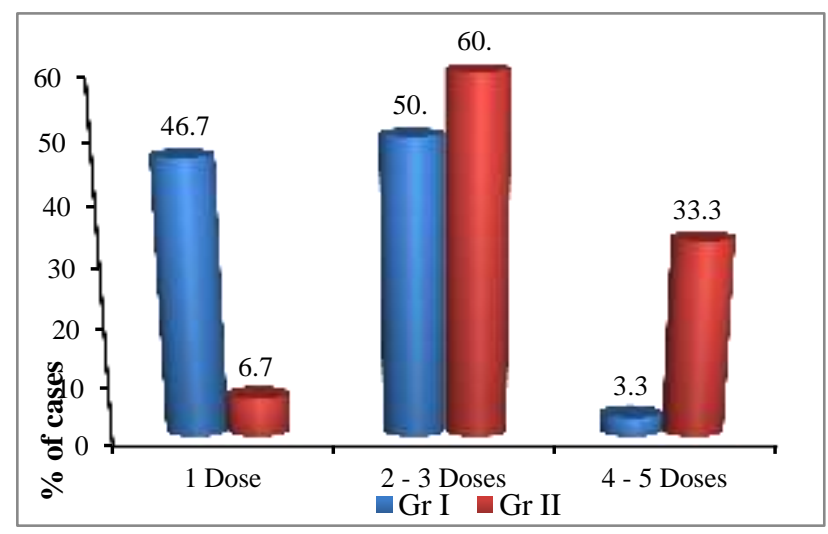

Figure 2: Comparison of number of doses of Misoprostol used in two groups.
Table 4: Induction - abortion interval.

\begin{tabular}{|lll|}
\hline $\begin{array}{l}\text { Ind- Ab Interval } \\
\text { (Hrs) }\end{array}$ & Group -I n (\%) & Group in (\%) \\
\hline$\leq 10$ & $27(90.0)$ & $17(56.7)$ \\
\hline $11-20$ & $3(10.0)$ & $11(36.7)$ \\
\hline $21+$ & - & $2(6.7)$ \\
\hline Total & 30 & 30 \\
\hline
\end{tabular}

Table 5: Comparison of induction - abortion interval between two groups.

\begin{tabular}{|c|c|c|c|}
\hline $\begin{array}{l}\text { Ind- Ab } \\
\text { interval (Hrs) } \\
\text { dosage }\end{array}$ & Group-I & Group-II & I V/S II \\
\hline Mean \pm SD & $6.2 \pm 3.1$ & $11.6 \pm 5.4$ & $\begin{array}{l}\mathrm{T}=4.72 \mathrm{P}< \\
0.05\end{array}$ \\
\hline Range & $3.0-140$ & $5.0-26.0$ & \\
\hline
\end{tabular}

$90 \%$ of patients in group I aborted in less than 10 hours and remaining $10 \%$ aborted in 11-20 hours. The mean was $6.2 \pm 3.1$ hours.

In group II $56.7 \%$ aborted in less than 10 hours, $36.7 \%$ aborted in 11-20 hours and $6.7 \%$ took more than 21 hours. The mean was $11.6 \pm 5.4$ hours.

The difference in distribution of induction abortion interval among the two groups was statistically significant.

The complete abortion rate in group I was $83 \%$ and group II was $80 \%$. The difference was statistically not significant.

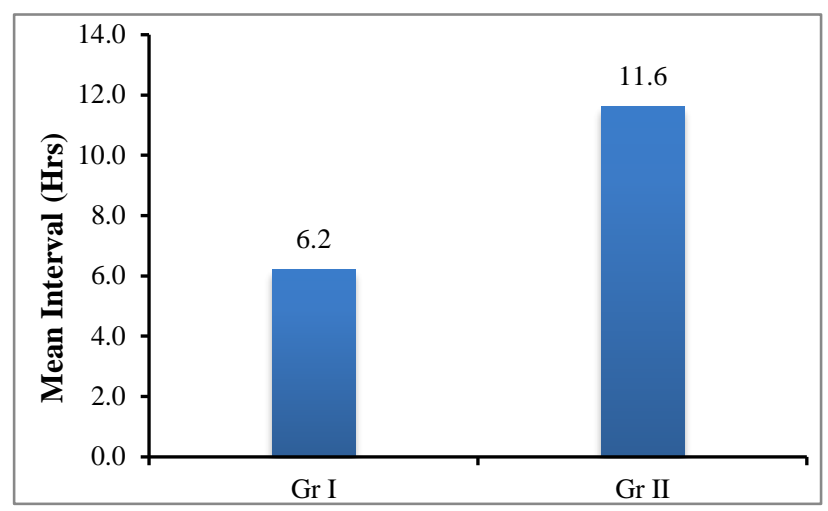

Figure 3: Mean induction abortion interval (hrs) in two groups.

In group I $10 \%$ of patients developed fever versus $(26.7 \%)$ in group II. $13.3 \%$ of patients in group I developed chills versus $36.7 \%$ in group II. $6.7 \%$ of patients in group I developed vomiting versus $13.3 \%$ in group II. No patients in group I had diarrhea while $6.7 \%$ patients in group II had diarrhea. 
Table 6: Complications in two group.

\begin{tabular}{|lll|}
\hline Complications & Group- I n (\%) & Group II n (\%) \\
\hline Fever & $3(10.0)$ & $8(26.7)$ \\
\hline Chills & $4(13.3)$ & $11(36.7)$ \\
\hline Vomiting & $2(6.7)$ & $4(13.3)$ \\
\hline Diarrhoea & - & $2(6.7)$ \\
\hline $\begin{array}{l}\text { No of cases } \\
\text { with } \\
\text { complications }\end{array}$ & $8(26.7)$ & $14(46.7)$ \\
\hline
\end{tabular}

Group I V/S Group II Z=1.64 P=0.10 NS

$26.7 \%$ of patients in group I had complications compared to $46.7 \%$ in group II. Over all group I had lesser complications than group II. But the difference in complications between the two groups was not significant statistically. No hospitalization or blood transfusion was needed for excessive bleeding.

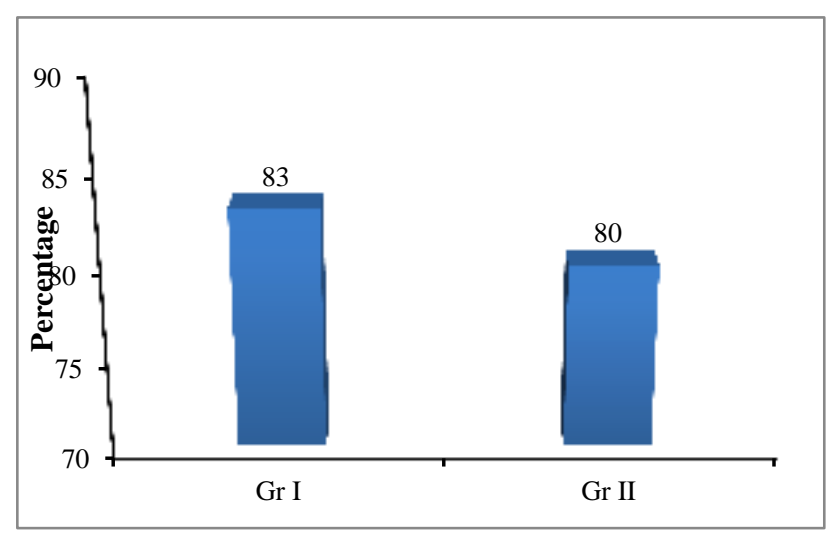

Figure 4: Complete abortion rate $(\%)$.

\section{DISCUSSION}

Amongst the prostaglandins misoprostol, a prostaglandin E1 analogue has been extensively used for induction of abortions in first and second trimester. There are many advantages in using misoprostol instead of other prostaglandins such as its low cost and easy storage facilities. The drug can be used orally, vaginally, sublingually or in combination in different dosages. A wide variety of dosage regimens are being used to effect second trimester pregnancy termination.

Mifepristone, a progesterone receptor antagonist is effective in shortening the induction to abortion interval when used in combination with prostaglandins. PGE1 analogues in combination with mifepristone offer the safest and expeditious method to induce abortion in the second trimester. ${ }^{4,14}$ Both WHO and RCOG recommend regimens in which mifepristone precedes use of either misoprostol or gemeprost. Many regimens and dosages are used routinely wit good efficacy. RCOG recommends $200 \mathrm{mg}$ of mifepristone orally on day one $36-48$ hours later misoprostol $800 \mu \mathrm{g}$ vaginally. Following that 3 hours later misoprostol 400 micrograms orally every 3 hours until delivery or total of 4 doses. ${ }^{3,4}$
As with first trimester abortion, randomized studies consistently indicated $200 \mathrm{mg}$ of mifepristone is equally effective as $600 \mathrm{mg}$ for termination of pregnancy in second trimester. ${ }^{5,6}$

Although vaginal misoprostol is more effective in the first trimester many studies have reported no difference in efficacy for second trimester abortion. ${ }^{7,8}$

Also it has often been found that absorption through the vaginal route is inconsistent and that the patients find vaginal administration uncomfortable. Oral misoprostol reaches a high peak concentration in blood very quickly followed by a rapid fall in plasma level. After vaginal administration there is gradual rise up to peak level and then a slow fall of level. ${ }^{9,10}$

In another study by El Rafaey et al, 70 women pretreated with mifepristone were randomized to receive vaginal or combination of vaginal and oral misoprostol. No significant difference was found between the two different routes of administration. The mean induction abortion interval was 6.4 hours. ${ }^{8}$

In a review of 1002 consecutive cases of medical termination of mid trimester pregnancy, 97.1\% aborted successfully within 5 doses of misoprostol. Surgical intervention was required in $8.1 \%$ women. It concluded that mifepristone in combination with misoprostol was safe and effective regimen for mid trimester medical abortion. 11

Bebbington MW, Kent N studied 114 women where the authors compared oral misoprostol $(400 \mu \mathrm{g})$ with that of vaginal misoprostol $(400 \mu \mathrm{g})$ for mid trimester pregnancy termination. They concluded that vaginal administration resulted in shorter induction - delivery interval. ${ }^{12}$

In a study by Dickinson JE et al, 150 women subjected to different intravaginal misoprostol regimens were compared. The regimens were- $200 \mu \mathrm{g}$ misoprostol at 6 hours interval (group 1), $400 \mu \mathrm{g}$ misoprostol (group 2) a loading dose of $200 \mu \mathrm{g}$ (group 3). The efficacy of $400 \mu \mathrm{g}$ at 6 hours interval proved the best

In our study, we found the number of doses of misoprostol required was more in oral route(mean dosage was $1.8 \pm 0.9$ and 3.0 \pm 1.3 .in vaginal and oral group respectively) and so was the induction abortion interval as compared to the vaginal route (The mean was $6.2 \pm 3.1$ hours in the vaginal group compared to $11.6 \pm 5.4$ hours in oral group) But there was no statistical difference in the complete abortion rate ( group I was $83 \%$ and group II was $80 \%$ ) Also, unlike expectation there was no statistical difference in the side effect profile in both groups. So though vaginal route would be more efficient and less time consuming, oral route also could be offered to those patients who preferred lesser vaginal examinations as the end result of complete abortion in both routes were the same. This study was limited by the 
small sample size of 60 patients and patient preference and comfort of the route used wasn't taken into consideration.

\section{CONCLUSIONS}

$200 \mathrm{mcg}$ misoprostol inserted vaginally every 3 hours is more effective than $400 \mathrm{mcg}$ of misoprostol administered orally 36 hours after administration of tab. Mifepristone $200 \mathrm{mg}$ for termination of second trimester pregnancy (13- 20 weeks) This regimen is a safe, cost effective, non surgical method with short induction-abortion interval than other known dosing intervals for mid trimester abortion.

\section{Competing interests}

We do not have any commercial association that might pose a conflict of interest in connection with the manuscript. We certify that neither this manuscript nor one with substantially similar content under our authorship has been published or is being considered for publication elsewhere.

Funding: No funding sources Conflict of interest: None declared

Ethical approval: The study was approved by the Institutional Ethics Committee

\section{REFERENCES}

1. Nagaria T, Sirmor N. Misoprostol Vs Mifepristone and Misoprostol in Second Trimester Termination of Pregnancy. J Obstet Gynaecol India. 2011;61(6):65962.

2. Kulier R, Kapp N, Gülmezoglu AM, Hofmeyr GJ, Cheng L, Campana A. Medical methods for first trimester abortion. Cochrane Database Syst Rev. $201 ; 11$.

3. Goldberg AB, Greenberg MB, Darney PD. Misoprostol and pregnancy. N Eng J Med. 2001;344:38-60.

4. Lalitkumar S, Bygdeman M. Gemzell - Danielsson K. Mid trimester induced abortion: a review. Hum Reprod Update. 2007;13:37-52.

5. Webster D, Penney GC, Templeton AA. A comparison of 600 and 200mg mifepristone prior to second trimester abortion with the prostaglandin misoprostol. Br J Obstet \& Gynecol. 1996;103:7069.

6. EL-Rafey, Rajasekhar D, Abdatta M. Colder L. Induction of abortion with mifepristone and oral and vaginal misoprostol. N-Eng J Med. 1995;332:983-7.

7. Nigam A, Singh VK, Prakash A. Vaginal Vs oral misoprostol for mid trimester abortion. Int $\mathrm{J}$ Gynaecol Obstet. 2006;92:270-1.

8. El-Rafaey H, Templeton A. Induction of abortion in the second trimester by a combination of misoprostol and mifepristone : a randomized comparison between two misoprostol regimens. Hum Reprod. 1995;10:475-8.

9. Guix C, Palacio M, Figueras F, Bennasar M, Zamora L, Coll O. Efficacy of two regimens of misoprostol for early second trimester pregnancy termination. Fetal Diagn Ther. 2005;20(6):544-8.

10. Tang OS, Schweer H, Seyberth HW, Lee SW, Ho PC. Pharmacokinetics of different routes of administration of misoprostol. Human Reprod. 2002;7(2):332-6.

11. Ashok PW, Templeton A, Wagaarachchi PT, Flett GMM. Mid trimester medical termination of pregnancy: A review of 1002 consecutive cases. Contraception. 2004;69:51-8.

12. Bebbington MW, Kent N, Lim K., Gagnon A, Delisle MF. A randomized controlled trial comparing two protocols for the use of misoprostol in midtrimester pregnancy termination. Am J Obstet Gynecol. 2002;187(4):853-7.

13. Dickinson JE, Evans SF. The optimisation of intravaginal misoprostol dosing schedules in second trimester pregnancy termination. Am J Obstet Gynecol. 2002;186(3):470-4.

14. Kapp N, Borgatta L, Stubblefield PG, Vragovic O, Moreno N. Mifepristone in mid trimester medical abortion: A randomized controlled trial. Obstet \& Gynecol. 2007;110:1304-10.

Cite this article as: Madhuri N, Veena GR, Manjunath GH. Randomised comparison of oral and vaginal misoprostol when combined with mifepristone for termination of second trimester pregnancy. Int J Reprod Contracept Obstet Gynecol 2016;5:509-13. 